\title{
Kajian 'Arkeologi Situs Masa Sejarah' Di Lasem: Pergeseran Pusat Kegiatan
}

\section{Nurhadi Rangkuti}

Keywords: north coast of java, history, city, development, movement

\section{How to Cite:}

Rangkuti, N. (1997). Kajian 'Arkeologi Situs Masa Sejarah' Di Lasem: Pergeseran Pusat Kegiatan. Berkala Arkeologi, 17(1), 38-48. https://doi.org/10.30883/jba.v17i1.768

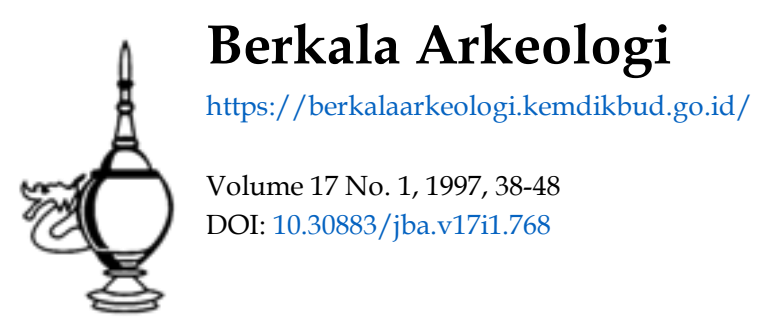

\section{(c) (1)(2) (2)}

This work is licensed under a Creative Commons Attribution-NonCommercial-ShareAlike 4.0 International License. 


\title{
KAJLAN 'ARKEOLOGI SITUS MASA SEJARAH' DI LASEM : PERGESERAN PUSAT KEGIATAN ${ }^{*}$
}

\author{
Nurhadi Rangkuti \\ (Balai Arkeologi Yogyakarta)
}

\section{Pendahuluan}

Istilah 'arkeologi situs masa sejarah' (historic sites archaeology) pertama kali muncul di Amerika ketika para pakar arkeologi di sana melakukan penelitian pada situs-situs yang pernah didiami oleh orang-orang Eropa yang pertama bermukim di Amerika (American civilization). Dalam hal ini 'arkeologi situs masa sejarah' didefinisikan sebagai penelitian arkeologi yang dilakukan di situs-situs yang mengandung bukti arkeologis dari kebudayaan non-Indian, atau yang berhubungan dengan data sejarah/dokumen yang sejaman kebudayaan non-Indian (Fontana 1978 :23).

Dalam arkeologi Indonesia, pengertian istilah 'arkeologi sejarah' dan 'prasejarah masih dipertentangkan (Nurhadi, 1986:6). Dalam wawasan yang sempit kedua istilah tersebut memilah penelitian terhadap rangkaian perkembangan budaya dalam dua kelas, yaitu dari bentang masa sebelum dan setelah ditemukannya simbol untuk tutur. Dalam wawasan yang luas, 'prasejarah' dan 'arkeologi sejarah' tidak menampilkan perbedaan yang mendasar, karena keduanya melakukan penelitian terhadap sasaran dan menjangkau tujuan yang sama, yaitu peninggalan budaya materiel dalam merekonstruksi perkembangan perikehidupan masa lalu. Perbedaannya hanya terbatas pada unit observasi dan analisis serta penyadapan informasinya (Nurhadi, 1985:6-7).

Untuk membedakan secara tegas antara 'arkeologi sejarah' (historical archaeology) dan 'prasejarah', maka dalam makalah ini digunakan istilah 'arkeologi situs masa sejarah'. Istilah ini mengacu pada penelitian arkeologi yang dilakukan pada situssitus masa sejarah yang berhubungan dengan data tertulis. Dalam penelitian 'arkeologi situs sejarah' periu dilakukan korelasi antara peninggalan material dan data verbal karena keduanya terlahir dari sistem budaya (Nurhadi, 1986:7). Pada dasarnya data arkeologi dan data sejarah mempunyai hakekat data yang berbeda. Data sejarah biasanya memuat event atau peristiwa sejarah, bersifat partikularistik, memuat nama-nama tokoh, sosial-politik dan isinya tersurat. Bertolak belakang dengan data srkeologi. berupa peninggalan budaya materiel yang bisu, dalam arti tidak akan berbicara sendiri tentang dirinya, tentang penciptanya dan operasinya dalam sistem budaya (Nurhadi, 1986:15). Data arkeologi hanya akan memberikan

Pemah dipresentasikan pada Diskusi Ilmiah Arkeologi III. diselenggarakan oleh LAAI Komda DKI - Jabar. Tahun 1988 di Jakarta 
informasi tentang dirinya sejauh peneliti mampu mengajukan rangkaian pertanyaan dala!n bentuk metode penyadapan informasi yang terarah pada kerangka teori yang diajukan (Nurhadi, 1986:15). Data arkeologi hanya memberikan informasi berupa event atau peristiwa budaya secara general dan tersirat. namun mampu mengungkapkan segala aspek budaya (totalitas).

Dalam menggunakan data sejarah, babad misalnya. haruslah memperhatikan keabsahan dan kebenarannya. Pada Babad Lasem yang digunakan dalam makalah ini banyak berisi hal-hal yang diragukan kebenarannya (Satara, 1983:487). Hal ini berkaitan dengan proses pembentukan data tertulis. sejak dari kelangsungan peristiwa, saksi mata, penulisnya hingga berada di tengan peneliti. Dalam proses tersebut telah terjadi pembiasan, pengurangan nilai, perubahan isi, penambahan bumbu dan berbagai bentuk distorsi lainnya (Nurhadi, 1986:18). Meskipun demikian bukan berarti informasi yang terdapat dalam data tertulis tidak dapat digunakan sama sekali. Babad Lasem masih dapat digunakan setelah dianalisis lebih dulu. bukan hanya sekedar dibaca saja. Bagaimanapun juga pesan verbal yang dikandungnya dapat dan harus diperhitungkan dalam penelitian arkeologi, baik dalam penyususnan kerangka penelitian maupun dalam identifikasi dan interpretasi peninggalan budaya materiel (Nurhadi, 1986:7). Pemanfaatan informasi dari Babad Lasem terbatas pada hal-hal tertentu saja dan itu pun harus bertolak pada 'archaeological judgement'. menempatkan data arkeologi di atas data sejarah karena penelitian arkeologi bertolak dari data arkeologi (Nurhadi, 1986).

\section{Situs Permukiman Lasem}

Orsoy de Flines merupakan penelitian yang pertama kali melakukan penelitian di daerah Lasem, Kabupaten Rembang, pada tahun 1940-1942, dengan tujuan untuk mengetahui permukiman kuno, terutama yang berasal dari abad ke-10 Masehi dan sebelumnya. Daerah Rembang yang diteliti meliputi Waru, Binangun, Kragan, dan Pamotan. Di Binangun yang masuk dalam Kecamatan Lasem, hampir tidak ditemukan keramik yang berasal dari masa sesudahnya.

Pada tahun 1975 Benet Bronson dan Teguh Asmar melakukan penelitian arkeologi di Kabupaten Rembang dan sekitarnya. Dalam penelitian tersebut dilakukan survei di daerah Lasem meliputi Candi Asu, Gebang, Kajar, Binangun, Pesanggrahan. Sriombo, dan Topar. Temuan arkeologis yang ditemukan berupa gerabah, keramik. pondasi batu bata, batu candi, lingga serta beberapa artefak dari masa prasejarah.

Penelitian arkeologi yang intensif di daerah Lasem dilakukan oleh Puslit Arkenas berturut-turut dari tahun 1979 hingga tahun 1986 yang meliputi Caruban. BonangBinangun, Kiringan. Darakandang, Sumbergirang, Ngempalak, Layur, Tasiksana. Selapura. dan Leran (masuk Kecamatan Sluke. Rembang). Peninggalan arkeologis yang ditemukan terdiri dari makam, struktur bata, batu candi, sumur kuno, keramik. gerabah, bandul jaring, kepeng, logam. lingga, pipisan, dan artefak-artefak lainnya. 
Semua peninggalan arkeologis di daerah Lasem tersebut di daerah pantai. dataran rendah, dan daerah Pegunungan Lasem. Dari hasil analisis artefak, diketahui bahwa Lasem merupakan situs permukiman yang cukup padat sejak abad ke-14 hingga ke17 Masehi; atau pada masa Klasik hingga awal persebaran agama Islam di pesisir utara Jawa.

Informasi mengenai tempat-tempat permukiman kuno di daerah Lasem tercantum dalam Babad Lasem yang ditemukan Puslit Arkenas tahun 1983. Naskah ini ditulis dalam huruf latin ejaan baru, dan merupakan salinan yang sangat resen dari isi sebuah babad yang bernama Pustaka Radrasanti, dikisahkan oleh Kamzah, seorang bangsawan Lasem yang hidup dalam tahun 1825 (Satari, 1983:487). Tempat-tempat permukiman tersebut meliputi masa Bhre Lasem memerintah pada tahun 1273 Saka sampai awal persebaran agama Islam, yaitu :

\section{Pelabuhan}

a. Kaeringan : Pelabuhan ini telah disebutkan sejak masa Dewi Indu (Bhre Lasem (1273 S) memerintah yang mana suaminya, Rajasawardana (Bhre Matahun) menguasai jung-jung perang di tempat ini. Kemudian pada masa persebaran agama Islam, Kaeringan sebagai pelabuhan tetap digunakan. Antara lain disebutkan Pangeran Santikusumo (lahir $1380 \mathrm{~S}$ ) pada usia 18 tahun naik perahu dari pelabuhan Kaeringan menuju Tuban. Ia meninggal dalam usia 50 tahun dikubur di Kaeringan.

b. Teluk Regol : Rajasawardana juga menguasai jung-jung perang di tempat ini. Bi Nang Un, seorang pedagang dari Campa, pada tahun 1335 Saka mendaratkan jung-jungnya di Teluk Regol. Kemudian Regol menjadi Binangun.

\section{Pusat Pemerintahan}

a. Keraton Kriyan : Keraton Dewi Indu (Bhre Lasem) yang memerintah pada tahun 1273 Saka. Di sebelah tenggara keraton ditanam pohon-pohon kamal (asam), sedangkan sepanjang jalan ditanami pohon sawo kecil. Keraton dihiasi ukir-ukiran dengan umpak berbentuk bunga teratai. Lantainya dibuat dari bata persegi yang besar dan halus. Atapnya ditutup dengan sirap. sedangkan bubungan atap dihias dengan genting berukir (Satari, 1983). Keraton ini selanjutnya ditinggali oleh keturunan Dewi Indu sampai pertengahan abad ke-15 Masehi.

b. Bonang-Binangun : Pangeran Wirabjra memindahkan keraton dari Kriyan ke bumi Bonang-Binangun pada tahun 1391 Saka. Putranya. Wiranegara. menjadi Adipati Binangun sampai tahun 1401 Saka.

c. Colegawan : Pada tahun 1402 Saka Putri Malokah memindahkan Kadipaten Bianangun ke Lasem di bumi Colegawan. berhadapan dengan keraton Kriyan. Istana Putri Malokah menghadap ke jalan besar dan ditanami pohon sawo kecik serta kantil. Selain itu dibangun pula taman di tepi pantai pesisir Kaeringan 
dekat Candi Samodrawela. Taman yang pada mulanya diberi nama "Taman Sitoresmi" lama-kelamaan berubah jadi "Taman Caruban" (Satari, 1983:489).

\section{Tempat Keagamaan}

a. Pucangan, bukit Ngenden : tempat Candi Ganapati masa Dewi Indu.

b. Gunung Agrasoka : tempat Candi Malad, tempat dicandikannya abu jenasah Dewi Indu dan Rajasawardana.

c. Butun : tempat asrama agama Siwa pada masa Dewi Indu

d. Bukit Gobang : tempat asrama agama Siwa pada masa Dewi Indu

e. Candi Samodrawala : tempat asrama agama Siwa yang memuja Dewa Waruna. Letaknya dekat Kaeringan.

f. Pamulang : tempat asrama agama Buddha pada masa Dewi Indu

g. Bukit Punggur : tempat asrama agama Buddha pada masa Dewi Indu

h. Ratnapangkaja : tempat asrama agama Buddha pada masa Dewi Indu

I. Bukit Regol Bonang : makam suami istri Ri Nang Ti dan Radeapala. Watu gilang yang ada di situ dijadikan pasujudan oleh Sunan Bonang

\section{Hipotesa dan Metode}

Berdasarkan peninggalan arkeologis dan Babad Lasem dapat dibangun hipotesa tentang pola permukiman situs Lasem. Secara semi-makro Lasem dipandang sebagai sebuah sistem permukiman lokal yang didiami oleh suatu komunitas, terdiri dari kelompok-kelompok sosial. Kelompok sosial ini dapat berupa tempat tinggaltempat tinggal (residential group) atau lembaga/institusi yang mengikat kehidupan bersama dalam satu komunitas terdapat berbagai macam status dan profesi dari para anggotanya, seperti raja, bangsawan, rakyat biasa, pendeta, pedagang, petani, nelayan dan sebagainya.

Dalam kurun waktu kira-kira 3 abad lebih lamanya, telah terjadi proses dan perkembangan di situs permukiman Lasem. Hal ini ditandai dengan adanya pergeseran lokasi pusat kegiatan (keraton) sejak masa 'klasik' hingga berkembangnya pengaruh agama Islam di daerah itu. Secara makna pergeseran pusat kegiatan tidak lepas dari perkembangan sosial, politik dan ekonomi yang terjadi pada daerah-daerah pesisir utara Jawa Tengah dan Jawa Timur.

Masalahnya adalah dimanakah lokasi pusat kegiatan yang pertama hingga bergeser ke tempat lain pada masa selanjutnya. Sampai dimanakah kesejajaran antara Babad Lasem dengan data arkeologi?.

Untuk itu perlu dilakukan korelasi antara data arkeologi dan data tertulis. Dalam hal imi dilakukan identifikasi terhadap tempat-tempat yang tercantum dalam Babad Lasem dengan bukti-bukti arkeologis. Secara semi-makro situs Lasem terdiri dari satuan-satuan ruang yang karakternya dapat dibedakan berdasarkan data arkeologi dan data lingkungan. 


\section{Identifikasi Satuan Ruang}

Penyalin terakhir Babad Lasem adalah seorang yang bernama R. Panji Karsono. Pada tahun 1830 ia telah mencoba mengidentifikasikan tempat-tempat yang disebut dalam Babad Lasem ke dalam lokasi-lokasi yang ada di daerah Lasem sekarang. Kemudian seorang ahli arkeologi, Sri Soejatmi Satari pada tahun 1983 juga telah melakukan usaha serupa dengan mengacu pada data arkeologis, toponim dan keadaan geografis daerah Lasem. Penelitian arkeologi pada tahun 1986 juga telah mengidentifikasikan tempat-tempat permukiman dalam Babad Lasem dengan data arkeologi.

\section{SEBARAN SITUS MASA SEJARAH DI DAERAH LASEM}

\begin{tabular}{|c|c|c|c|}
\hline Lokasi & Zona & Temuan Arkeologis & Babad Lasem \\
\hline $\begin{array}{l}\text { Kec. Rembang } \\
\text { 1. Kiringan }\end{array}$ & pantai & $\begin{array}{l}\text { Struktur bata. gerabah, } \\
\text { keramik, kepeng, bandul } \\
\text { jaring, sisa makanan (*) }\end{array}$ & Pelabuhan Kaeringan \\
\hline $\begin{array}{l}\text { Kec. Lasem } \\
\text { 2. Caruban }\end{array}$ & pantai & $\begin{array}{l}\text { Makam, sumur, struktur } \\
\text { bata, lingga, kepeng, pi- } \\
\text { pisan, keramik, gerabah. } \\
\text { terak besi, sisa makanan } \\
\left({ }^{*}\right)\end{array}$ & $\begin{array}{lr}\text { Candi } & \text { Samodrawala, } \\
\text { keraton } & \text { Cologawan. } \\
\text { makam } & \end{array}$ \\
\hline $\begin{array}{l}\text { 3. Gedongmulyo } \\
\text { (dk. Layur) }\end{array}$ & pantai & keramik (") & - \\
\hline 4. Tasiksana & pantai & keramik (*) & Candi Pucangan \\
\hline 5. Bonang & $\begin{array}{l}\text { pantai / } \\
\text { bukit }\end{array}$ & $\begin{array}{l}\text { Makam, masjid, sumur, } \\
\text { pasujudan Bonang, kera- } \\
\text { mik, pipisan }(*, * *, * * *)\end{array}$ & $\begin{array}{l}\text { Makam Bi Nang Ti dan } \\
\text { Badranala, pasu-judan } \\
\text { Bonang, Kadipaten Bi- } \\
\text { nangun Lasem }\end{array}$ \\
\hline 6. Binangun & $\begin{array}{l}\text { pantai / } \\
\text { bukit }\end{array}$ & $\begin{array}{l}\text { Sumur, makam, bata, batu } \\
\text { candi, keramik, manik- } \\
\text { manik, terak besi (*. **, } \\
* * *)\end{array}$ & Pelabuhan Regol \\
\hline 7. Darkandang & dataran & $\begin{array}{l}\text { Sumur, bata kuno, keramik } \\
\text { (*) }\end{array}$ & - \\
\hline 8. Selapura & dataran & $\begin{array}{l}\text { bata kuno, pecahan wadah- } \\
\text { wadah besar dari tanahliat } \\
\text { (*) }\end{array}$ & - \\
\hline
\end{tabular}




\begin{tabular}{|c|c|c|c|}
\hline 9. Sumbergirang & dataran & $\begin{array}{l}\text { Struktur bata. sumur. } \\
\text { keramik (*) }\end{array}$ & $\begin{array}{l}\text { Keraton Kriyan Dewi } \\
\text { Indu }\end{array}$ \\
\hline 10. Ngemplak & dataran & sumur $(*)$ & \\
\hline 11. Gebang & bukit & Lingga, arca Nandi (**) & $\begin{array}{l}\text { Asrama pendeta agama } \\
\text { Siwa }\end{array}$ \\
\hline 12. Kajar & dataran & $\begin{array}{l}\text { batu candi, bata lingga } \\
(* *)\end{array}$ & - \\
\hline 13. Topar & dataran & Umpak batu (4 buah) (**) & - \\
\hline
\end{tabular}

$$
\begin{aligned}
\text { Keterangan : * } & : \text { Penelitian Puslit Arkenas (1979 _- 1986) } \\
& \text { ** }: \text { Penelitian Teguh Asmar dkk (1975) } \\
* * * & \text { : Penelitian Orsoy de Flines (1941 - 1942) }
\end{aligned}
$$

Dari belasan lokasi peninggalan arkeologis yang ditemukan di daerah Lasem, ada beberapa lokasi yang dianggap relevan dan bermakna dalam kajian di sini, yaitu :

\section{Caruban}

Letaknya bersebelahan dengan Kiringan yang dibatasi oleh Sungai Kiringan di sebelah barat Caruban. Dari hasil analisis pola artefak Caruban diketahui bahwa tempat ini merupakan situs habicasi yang diisi dengan kegiatan rumahtangga seharihari, sejak kira-kira abad ke-14 hingga abad ke-17 Masehi. Kegiatan yang utama di Caruban adalah kegiatan yang konsumtif (memperoleh, menyimpan, memasak, dan menyajikan makanan dan minuman) yang dilengkapi dengan kegiatan lainnya, seperti kegiatan individu, dekorasi rumah, perayaan dan permainan, meramu obatobatan, menangkap ikan dan sebagainya (Rangkuti, 1986).

Menurut Babad Lasem di daerah ini telah didiami manusia sejak masa Dewi Indu hingga masa perkembangan agama Islam. Pada masa Dewi Indu disebutkan sebuah tempat asrama Siwa, letaknya dekat Kaeringan dan di situ berdiri Candi Samodrawela. Di Caruban tidak ditemukan bangunan tersebut. Namun di situ dulu pernah ditemukan fragmen candi berupa kala makara (Satari, 1983:494) dan sebuah lingga dari batu andesit yang ditemukan dalam penelitian arkeologi tahun 1985. Temuan-temuan tersebut merupakan indikasi adanya kegiatan agama Siwa di
Caruban.

Pada masa Isiam disebutkan adanya keraton Puteri Malokah (1402 S) dengan tamannya yang bernama 'Taman Caruban'. letaknya di pesisir Kaeringan dekat Candi Samodrawela. Di Caruban sekarang terdapat kompleks makam Nyi Ageng 
Maloko. Di dekatnya, sebelah barat, ditemukan sisa-sisa struktur bata ketika penduduk membangun pesantren di situ. Selain itu di sekitar makam terdapat pohon-pohon sawo kecik. Di sebelah barat Caruban terdapat makam Sayid Abubakar yang dikelilingi tembok bata kuno yang kini tinggal sisanya. Di situ. dahulu ada sebuah gapura bata yang dihias dengan hiasan kala (Satari, 1983:494). Selain itu juga di Caruban terdapat sumur-sumur kuno ( 9 buah) berupa sumur terakota dan sumur persegi dari bata.

Berdasarkan peninggalan arkeologis tersebut dan dikorelasikan dengan hasil analisis pola artefak dari hasil ekskavasi, maka Caruban mempunyai peluang besar sebagai lokasi pusat kegiatan (keraton Putri Malokah); seperti yang diduga oleh Soejatmi Satari (1983).

\section{Kiringan}

Letaknya di sebelah barat Caruban. Dalam ekskavasi tahun 1986 ditemukan pondasi bata yang memanjang arah utara-selatan, namun belum diketahui seberapa panjangnya. Struktur ini berasosiasi dengan fragmen gerabah keramik, tulang, gigi. dan moluska. Meskipun belum dilakukan kajian kuantitatif untuk mengenali pola artefak seperti yang dilakukan di Caruban, secara kualitatif assemblage artefak di Kiringan tidak beda jauh dengan Caruban, yaitu menggambarkan kegiatan seharihari di situs habitasi.

Menurut Babad Lasem, Kaeringan yang letaknya di daerah pantai merupakan pelabuhan yang digunakan sejak masa 'klasik' hingga masa berkembangnya agama Islam. Namun sejauh penelitian belum diketahui secara pasti jenis-jenis artefak yang menjadi indikasi suatu pelabuhan. Satu hal yang perlu dipertimbangkan adalah di Kiringan ditemukan sebaran keramik yang cukup padat yang sebagian besar berasal sejak abad ke-14 hingga ke-17 Masehi. Dari temuan keramik tersebut, terdapat banyak pecahan botol dari tanahliat merah tanpa glasir yang berasal dari Thailand abad ke-15 (menurut identifikasi Abu Ridho) yang tidak dijumpai di Caruban atau lokasi-lokasi lainnya di daerah Lasem. Selain itu juga nama Kiringan dapat dikembalikan dengan nama Kaeringan dalam Babad Lasem dan letaknya sekarang sesuai pula dengan informasi yang terdapat dalam data tertulis tersebut.

\section{Bonang-Binangun}

Lokasi Bonang-Binangun yang disurvei meliputi daerah pantai dan perbukitan. Di Bonang terdapat Masjid Bonang dan sumur kuno dalam halaman masjid. Selain itu jugta terdapat pasujudan Bonang seperti yang tertera dalam Babad Lasem yang letaknya di bukit Bonang (Babad Lasem = bukit Regol Bonang). Di sekitar Teluk Binangun ditemukan dua buah sumur kuno dari bata dan di daerah perbukitan (dukuh Jejeruk) terdapat sisa-sisa struktur dari bata dan batu alam. 
Dalam babad Lasem, daerah Bonang-Binangun merupakan pelabuhan dan pusat kegiatan. Namun berdasarkan survei permukaan, ditemukan sedikit sekali keramik. yang umumnya berasal dari masa dinasti Song, Ming, dan Sawankhalok (Orsoy de Flines. 1947). Meskipun demikian, letak dan situasi Teluk Binangun sangat baik untuk pelabuhan (Satari, 1983:495) dan lagi pula di sekitarnya ditemukan sumur kuno yang menjadi indikasi tempat ini sebagai situs habitasi. Untuk itu perlu diadakan ekskavasi untuk mengetahui secara pasti lokasi pusat kegiatan.

\section{Sumbergirang}

Lokasi yang disurvei meliputi Dukuh Demungan, Dukuh Sumurkepel dan Desa Sumbergirang sendiri, yang letaknya di dataran rendah di sebelah timur Kota Lasem sekarang. Di daerah ini banyak ditemukan struktur bata kuno, antara lain di Balai Desa Sumbergirang dan tanah makam penduduk. Menurut keterangan penduduk. struktur bata yang terdapat di tanah makam sangat panjang yang menghadap arah barat-timur. Pengecekan langsung di lapangan memberikan gambaran, reruntuhan struktur tersebut diperkirakan panjangnya lebih dari 25 meter. Di sekitarnya ditemukan dua buah sumur kuno dari bata dan pecahanpecahan keramik.

Semua peninggalan arkeologis di Sumbergirang memberikan indikasi sebagai pusat kegiatan. Untuk itu perlu diadakan penelitian arkeologi lebih lanjut dengan melakukan ekskavasi.

Selain lokasi-lokasi peninggalan arkeologis yang telah disebutkan di atas, masih banyak lagi peninggalan arkeologis yang tersebar di daerah Lasem. Di Bukit Gebang, misalnya, ditemukan lingga dan arca Nandi yang memberikan indikasi kegiatan keagamaan. Dalam Babad Lasem diberitahukan tentang lokasi asrama agama Siwa di bukit Gebang. Selain itu banyak lokasi lainnya dalam Babad Lasem yang tidak dapat diidentifikasikan dengan bukit-bukit arkeologis dan sebaliknya dalam penelitian arkeologi telah ditemukan peninggalan arkeologis masa sejarah yang lokasinya tidak dapat diidentifikasikan dalam Babad Lasem. seperti Kajar, Topar, Ngemplak, dan Darakandang. Meskipun demikian lokasi dapat inenjadi bagian dari sistem permukiman Lasem masa lalu.

\section{Pergeseran Pusat Kegiatan}

Dalam Babad Lasem tercatat peristiwa pergeseran pusat kegiatan yang ditandai dengan berpindahnya keraton dari Kriyan ke Bonang-Binangun dan akhirnya dipindah lagi ke Colegawan. Dua lokasi pusat kegiatan yaitu Bonang-Binangun dan Colagawan terjadi pada masa berkembangnya penganuh agama Islam di daerah pesisir utara Jawa Tengah dan Jawa Timur. Kedua lokasi pusat kegiatan tersebut berada di daerah pantai, yaitu di Bonang-Binangun dan Caruban. Dipindahkannya lokasi pusat kegiatan di daerah pantai tidak mustahil karena disebabkan semakin 
ramainya perdagangan pada masa timbulnya Demak. sebagai kerajaan Islam di daerah pesisir. Kota-kota pelabuhan antara lain Tuban. Jepara, Gresik, dan Sedayu mengalami perkembangannya kembali, setelah mengalami masa kemunduran seiring dengan jatuhnya kerajaan Majapahit. Hal itu antara lain disebabkan karena kunci pelayaran dan perdagangan terbentang antara Selat Malaka melalui pesisir utara Jawa sampai Maluku sebagian besar ada di tangan pedagang-pedagang Muslim (Sartono Kartodirdjo, 1977:150). Dari berita-berita Portugis abad ke-17 dan berita VOC diketahui bahwa kapal-kapal dari Jawa mengadakan perdagangan di seluruh Nusantara hingga ke Asia Tenggara dan Philiphina. Pusat-pusat perdagangan yang terpenting pada waktu itu adalah Tuban, Gresik, Jepara termasuk juga Sedayu. Di tempat-tempat itu terdapat seribu perahu atau lebih. Warungwarung darurat dibuat di tepi pantai untuk menjual dagangan (Satari, 1983:496).

Dalam berita Belanda disebutkan banyak kapal-kapal Jawa dibuat di Banjarmasin. Jenis kapal yang lebih kecil dibuat di Lasem, sebab di daerah itu kayunya baik untuk dibuat perahu. Di Lasem hutan-hutannya menghasilkan kayu yang baik untuk dibuat kapal. Daerah pedalamannya yang subur menghasilkan beras dan hasil bumi lainnya (Satari, 1983:496).

Yang menarik perhatian adalah kedua lokasi pusat kegiatan berada dekat pelabuhan, yaitu Bonang-Binangun dengan pelabuhan Regol atau Binangun, dan Colegawan dekat depan pelabuhan Kaeringan. Hal ini memberikan petunjuk bahwa pada masa berkembangnya pengaruh agama Islam, kegiatan utama berorientasi pada perdagangan. dalam Babad Lasem disebutkan Pangeran Wirabajra pada tahun 1391 Saka memindahkan keraton ke Bonang-Bianangun, karena tempat itu mulai menjadi pusat agama Islam dan perdagangan laut bertambah ramai dengan berlabuhnya para pedagang dari Tuban, Gresik, dan Ngampel.

Pada masa Dewi Indu (1273 Saka) pelabuhan Regol dan pelabuhan Kaeringan telah digunakan sebagai pelabuhan. Diduga sistem pemerintahan Bhre Lasem tak beda jauh dengan sistem pemerintahan masa Majapahit pada umumnya, yaitu sebagai bagian dari negara agraris mempunyai pelabuhan-pelabuhan di pantai tempat mengekspor dan mengimpor keperluan penduduknya (Satari, 1983:495). Sebagaimana Majapahit. mungkin pusat kegiatan masa Dewi Indu berada di pedalaman atau agak jauh dari pantai. Dengan demikian lokasi yang mempunyai peluang sebagai pusat kegiatan masa Dewi Indu adalah daerah Sumbergirang, yang letaknya di dataran rendah.

\section{Penutup}

Hasil kajian mengenai arkeologi situs masa sejarah di Lasem baru bersifat umumnya dan sementara. Untuk mempertajam analisis data arkeologi yang terdapat pada situs sejarah. maka perlu dilakukan kajian kuantitatif untuk mengenal pola artefaknya. Pengenalan pola artefak baru dilakukan di Caruban saja (Rangkuti. 
1986). Kiranya perlu dilakukan hal yang serupa pada lokasi-lokasi lainnya dengan menggunakan prosedur yang sama pula. Setelah setiap lokasi diketahui pola artefaknya maka diketahui proses-proses budaya yang terjadi di situs Lasem, yang sekaligus dapat mengecek kebenaran data tertulis.

\section{KEPUSTAKAAN}

Fontana, Bernard, L., 1978. On the Meaning of Historic Sites Archaeology, dalam Historical Archaeology : A Guide to Substantive and Theorical Contributions (Ed. Robert L. Schuyler) : 23--26, New York : Baywood Publishing Company, Inc.

Nurhadi, 1985. Urban Archaeology in Indonesia : Restrospect and Prospect. Tesis University of Pennsylvania

1986. Penelitian Arkeologi Banten : Kemarin, Kini, dan Nanti, dalam Analisis Penelitian Arkeologi Banten 1986 (Pandeglang, 5 - 9 Desember 1986) belum diterbitkan.

Orsoy de Flines, 1941-47, Research Into the Ceramics Sherds in the Territory of Northern Central Java, 1940-42 OV, bij A : 66-84

Rangkuti, Nurhadi, 1986, Analisis Pola Artefak Situs Permukiman di Caruban, Lasem, dalam Pertemuan Ilmiah Arkeologi IV (Cipanas, 3 - 9 Maret 1986) : hlm. 133-159. Jakarta : Pusat Penelitian Arkeologi Nasional.

Sartono Kartodirdjo, dkk, 1977, Sejarah Nasional Indonesia III, Jakarta : Departemen Pendidikan dan Kebudayaan.

Satari, Sri Soejatmi, 1985, Caruban, Lasem : Suatu Situs Peralihan Klasik - Islam, Pertemuan Ilmiah Arkeologi III (Ciloto, 23 - 28 Mei 1983) : 487-499. Jakarta : Pusat Penelitian Arkeologi Nasional Departemen Pendidikan dan Kebudayaan.

South, Stanley, 1977, Method and Theory in Historical Arehaeology. New York : Academic Press. 


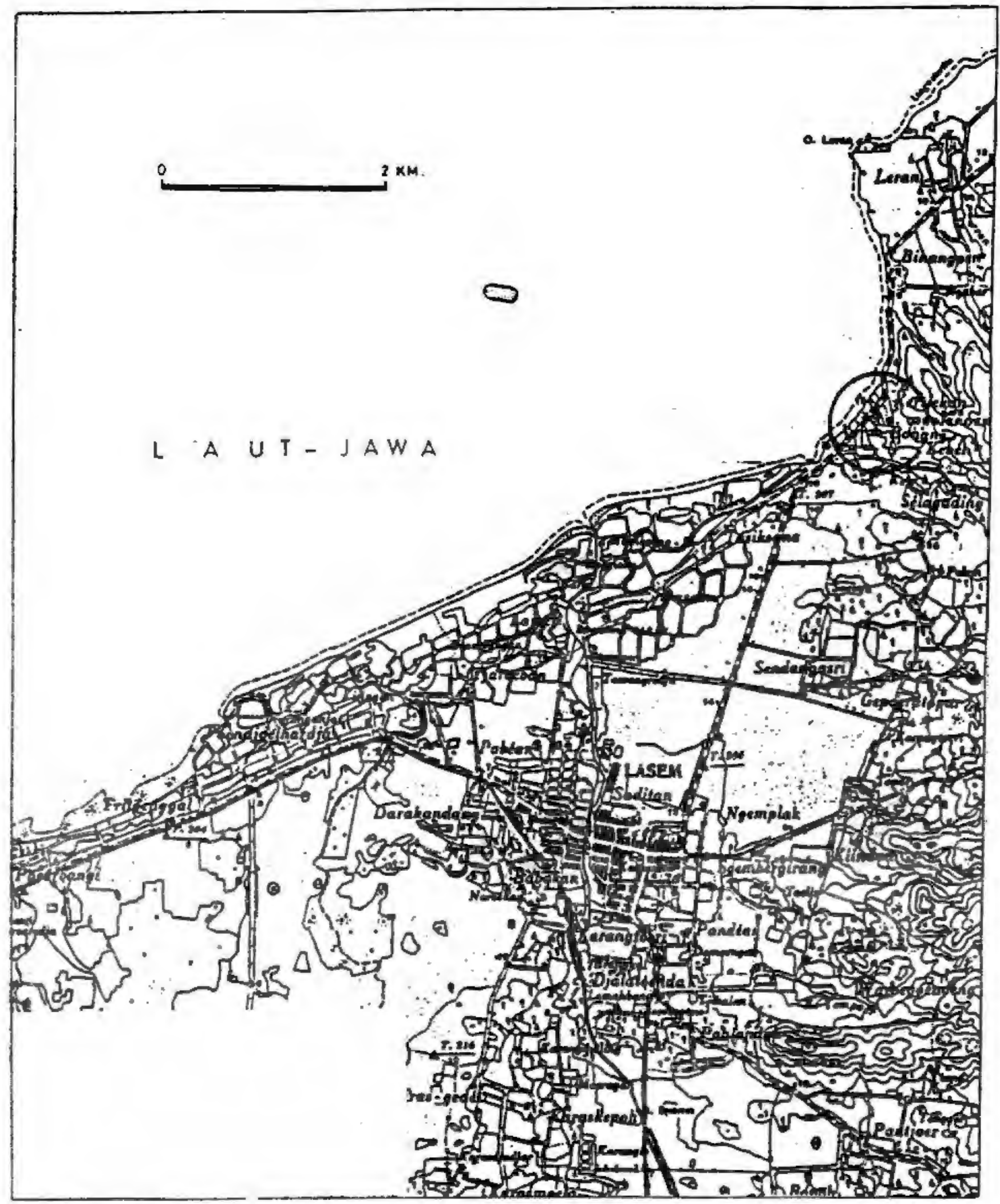

Peta Lokasi situs Lasem di kabupaten Rembang Jawa Tengah 